\title{
Molecular Mapping and Validation of SrND643: A New Wheat Gene for Resistance to the Stem Rust Pathogen Ug99 Race Group
}

\author{
Bhoja R. Basnet, Sukhwinder Singh, Eric E. Lopez-Vera, Julio Huerta-Espino, Sridhar Bhavani, Yue Jin, \\ Matthew N. Rouse, and Ravi P. Singh
}

First, second, third, and eighth authors: International Maize and Wheat Improvement Center (CIMMYT), Mexico D.F. 06600, Mexico; third author: CINVESTAV-IPN, Col. San Pedro Zacatenco, Mexico D.F. 07360, Mexico; fourth author: INIFAP CEVAMEX, Chapingo 56230, Edo. Mexico, Mexico; fifth author: CIMMYT, Nairobi, Kenya; and sixth and seventh authors: United States Department of AgricultureAgricultural Research Service Cereal Disease Laboratory, St. Paul, MN 55108.

Accepted for publication 11 October 2014.

\begin{abstract}
Basnet, B. R., Singh, S., Lopez-Vera, E. E., Huerta-Espino, J., Bhavani, S., Jin, Y., Rouse, M. N., and Singh, R. P. 2015. Molecular mapping and validation of $S r N D 643$ : A new wheat gene for resistance to the stem rust pathogen Ug99 race group. Phytopathology 105:470-476.

This study reports the identification of a new gene conferring resistance to the Ug99 lineage of races of Puccinia graminis f. sp. tritici in wheat (Triticum aestivum L.). Because the virulent races of stem rust pathogen continue to pose a serious threat in global wheat production, identification and molecular characterization of new resistance genes remains of utmost important to enhance resistance diversity and durability in wheat germplasm. Advanced wheat breeding line 'ND643/2*Weebill1' carries a stem rust resistance gene, temporarily designated as $\mathrm{SrND643,}$ effective against the Ug99 group of $P$. graminis f. sp. tritici races at both seedling and adult growth stages. This study was conducted to map the

chromosomal location of SrND643 and identify closely linked molecular markers to allow its selection in breeding populations. In total, 123 recombinant inbred lines, developed by crossing ND643/2*Weebill1 with susceptible line 'Cacuke', were evaluated for stem rust response in field nurseries at Njoro, Kenya, during two growing seasons in 2010, and were genotyped with DNA markers, including Diversity Arrays Technology, simple sequence repeats (SSR), and single-nucleotide polymorphisms. Linkage mapping tagged SrND643 at the distal end of chromosome 4AL, showing close association with SSR markers Xgwm350 ( 0.5 centimorgans $[\mathrm{cM}]), X w m c 219(4.1 \mathrm{cM})$, and $X w m c 776(2.9 \mathrm{cM})$. The race specificity of $\operatorname{SrND} 643$ is different from that of $S r 7 a$ and $S r 7 b$, indicating that the resistance is conferred by a gene at a new locus or by a new allele of $\operatorname{Sr} 7$. The flanking markers Xgwm350 and Xwmc219 were predictive of the presence of $\operatorname{SrND643}$ in advanced germplasm, thus validating the map location and their use in marker-assisted selection.
\end{abstract}

Wheat stem rust, caused by Puccinia graminis f. sp. tritici Erikss. \& Henning, can cause severe yield losses in wheat (Triticum aestivum L.). Several stem rust epidemics have been recorded in various regions $(22,24,28)$; severe stem rust epidemics can cause $100 \%$ losses in individual fields of susceptible cultivars (31). The emergence of $P$. graminis f. sp. tritici race TTKSK $(11,29)$, commonly known as Ug99, threatened global wheat production because of its virulence spectrum that defeated several stem rust resistance $(\mathrm{Sr} r)$ genes which were otherwise considered effective. Seven new variants within the Ug99 lineage have been identified, including variants with virulence to genes $\mathrm{Sr} 24$ and $\mathrm{Sr} 36$. This has further reduced the number of genes effective against the Ug99 race group $(11,12)$.

Races in the Ug99 lineage have already spread over a wide geographical area, including most countries in the East African highlands, Zimbabwe, South Africa, Sudan, Yemen, and Iran, and there is a high chance of spread into the wheat-growing belts of Asia, which presents a global concern (34). Singh et al. (34) reported that more than $90 \%$ of wheat cultivars grown worldwide were susceptible to races in the Ug99 lineage; thus, the incorporation of resistance into new cultivars and their rapid dissemination to farmers will be vital in reducing the risk of epidemics and associated large yield losses in vulnerable areas.

The majority of the 58 characterized stem rust resistance genes, originating from Triticum and related species (21), confer race-

Corresponding author: R. P. Singh; E-mail address: R.Singh@cgiar.org

http://dx.doi.org/10.1094/PHYTO-01-14-0016-R

(C) 2015 The American Phytopathological Society specific resistance that is effective at both the seedling and adult plant growth stages. However, the Ug99 group of races carries virulence to many of these genes, including $\mathrm{Sr} 31, \mathrm{Sr} 24, \mathrm{Sr} 36$, and $\mathrm{Sr} 38$, which are common in wheat cultivars worldwide $(10,12,27,33,34)$. A viable strategy for breeding wheat cultivars with durable resistance is to use complex race-nonspecific resistance, which is usually triggered at the adult plant stage. $\mathrm{Sr} 2$ is one of the most studied and widely distributed adult plant resistance (APR) genes $(35,42)$; however, when present alone under epidemic conditions, this gene does not provide adequate protection and disease severities can reach 60 to $70 \%$ (35). Singh et al. (37) proposed that at least four to five APR genes are needed to confer a near-immune response to rust but combining these genes in a single, high-yielding cultivar can be a difficult task. High levels of rust resistance can also be achieved when a moderately effective race-specific gene is combined with APR genes $(2,4,33,36)$.

To accelerate the development of cultivars resistant to virulent African stem rust races, new sources of resistance need to be identified, along with close molecular markers to enable their selection. Sr33 and Sr35 all-stage resistance genes effective against the $\mathrm{Ug} 99$ group of $P$. graminis $\mathrm{f}$. sp. tritici races have been isolated $(25,32)$. SrCad is another example of a newly characterized racespecific gene present in the Canadian wheat 'AC Cadillac' and 'Peace' (9). Like $\mathrm{SrCad}$, some lines from the International Maize and Wheat Improvement Center (CIMMYT) carry moderately effective race-specific resistance genes that map to chromosome 6DS (19). Other race-specific genes newly postulated and being used in the CIMMYT breeding program are $\mathrm{SrSha7}$ derived from Chinese 'Shanghai\#7', SrHuw234 derived from 'HUW234', and SrND643 derived from the North Dakota wheat 'ND643' (34). 
Molecular mapping of these genes will help to identify closely linked molecular markers that will expedite breeding for rust resistance through marker-assisted selection.

ND643 was used in crosses with CIMMYT germplasm to introgress the high protein content gene $g p c-B 1$. Several progeny of these crosses demonstrated seedling (all-stage) resistance to race TTKSK. The resistance gene from ND643 was postulated to be SrND643 (34). SrND643 is a moderately effective stem rust resistance gene present in the CIMMYT spring wheat 'ND643/ $2 *$ Weebill1'. At the seedling stage, SrND643 produces an infection type of 2 to $22^{+}$against races TTKSK and TTKST, belonging to the Ug99 lineage, while, in the adult plant stage, disease severity ranges from 10 to $40 \%$. The CIMMYT bread wheat improvement program has developed several ND643-derived high-yielding lines that carry SrND643 and are distributed in international nurseries and trials. The Kenya Agricultural Research Institute (KARI) recently released two wheat varieties, 'Kenya Tai' and 'Kenya Sunbird', that are postulated to carry $\operatorname{SrND643}$ and were selected from CIMMYT advanced lines derived from the cross ND643/2*Weebill1.

Given the importance of $\operatorname{SrND643}$, our study aimed to (i) map the genome location of SrND643 using a 'Cacuke//ND643/ $2 *$ Weebill1' recombinant inbred line (RIL) population and (ii) identify molecular markers closely linked with $\operatorname{SrND643}$ and validate their efficiency in marker-assisted selection.

\section{MATERIALS AND METHODS}

Plant materials. A mapping population comprising $123 \mathrm{~F}_{4: 5}$ RILs was developed by crossing ND643/2*Weebill1 (CIMMYT germplasm identification number [GID] 6302736) with susceptible line Cacuke (GID 6302734). The North Dakota State University line ND643 (CIMMYT GID 122735) was selected as a high-protein line from the three-way cross 'RL4352-1/T. dicoccoides FA-15-3// Len', where RL4352-1 was a rust-resistant selection from Canadian 'Columbus' (13) and Len was derived from the cross 'ND499/3/Justin/RL4205//Wisc261' (http://www.ars-grin.gov). The T. dicoccoides accession was included in the cross in order to introgress a gene, $G p c-B 1$, for high grain-protein content. Similarly, Weebill1 and Cacuke were selected at CIMMYT from the crosses 'Babax/Amadina//Babax' and 'Canadian/Cunningham//Kennedy'. The RIL population from the cross Cacuke//ND643/2*Weebill1 was developed by single-head descent (3).

Evaluations for stem rust resistance. Parents and RILs were evaluated for field reactions to race TTKST at the KARI, Njoro, Kenya during the 2010 off season and main growing season. The off-season rust-screening nursery was planted during December and harvested in April, whereas the main season began in June and ended in October. About $4 \mathrm{~g}$ of seed of each RIL and parent was planted in $0.7 \mathrm{~m}$ long paired-row plots, with spacing of $0.3 \mathrm{~m}$ between them. To initiate infection and establish stem rust epidemics in the nursery, spreaders (consisting of a mixture of Cacuke and six Sr24-carrying lines: CIMMYT GID 5391050, 5391052, 5391056, 5391057, 5391059, and 5391061) were planted as hill plots on one side of each test plot in the middle of $0.3-\mathrm{m}$-wide pathways. Spreaders were also planted along the borders of the experimental field in 1-m plots. To create uniform disease epidemics, spreaders were inoculated with a field bulk collection of race TTKST (11) 6 to 8 weeks after planting, using the method described by Njau et al. (23). Disease responses on each RIL and parent were recorded postflowering, when the susceptible parent displayed moderately susceptible to susceptible responses with $80 \%$ disease severity.

Host responses were based on the shape and size of uredinia on the stems (30), where $\mathrm{R}=$ resistant, $\mathrm{MR}=$ moderately resistant, MRMS or $\mathrm{M}=$ moderately resistant to moderately susceptible, $\mathrm{MS}=$ moderately susceptible, MSS = moderately susceptible to susceptible, and $\mathrm{S}=$ susceptible. To further analyze disease responses as a monogenic trait, RIL families were classified as resistant when they displayed low infection responses of $\mathrm{R}$, $\mathrm{MR}$, or $\mathrm{M}$, or as susceptible if they displayed high infection responses of MS or S. The binary classification of RILs was finally used to map the resistance gene in the chromosome. Families with both resistant and susceptible plants were classified as segregating. The percent disease severity was also recorded in the main season, following the modified Cobb Scale (26), and these data were used to conduct mapping of SrND643 using disease severity scores.

Molecular marker analysis and genetic mapping. In order to identify the chromosomal location of SrND643 in the Cacuke// ND643/2*Weebill1 population, we used both selective genotyping and bulk segregant analysis techniques. For selective genotyping, 46 entries (the parents plus 22 resistant and 22 susceptible lines) were genotyped using Diversity Arrays Technology (DArT) markers at Triticarte Pty Ltd., Australia (1). Genomic DNA extraction, quantification, and quality analyses were carried out using CIMMYT laboratory protocols (5). Resistant and susceptible bulks were prepared by mixing equal amounts of DNA from 10 homozygous resistant and 10 homozygous susceptible lines, which were selected as corresponding subsets of 44 lines used in selective genotyping. In all, 48 simple sequence repeat (SSR) markers previously mapped on chromosome $4 \mathrm{~A}(7,38-40)$ were used to survey polymorphisms between the parents and bulks. The primer sequences and annealing temperatures for all SSR markers were obtained from the GrainGenes database (http://wheat.pw.usda. gov). Similarly, the DNA sequence of DArT marker wPt-7590 was obtained from the DArT website (http://www.diversityarrays.com/ sequences.html) and the forward (5'-CGTCCAATGTTTGCTCA GAA- $3^{\prime}$ ) and reverse (5'-GCAACTACGGGGGTAATTGTT-3') primers were designed using the primer-BLAST program (http:// blast.ncbi.nlm.nih.gov). Similarly, four single-nucleotide polymorphism (SNP) markers (BS00016097, BS00013985, BS00020741, and BS00018740) developed by LGC Genomics Ltd. (http://www. $\operatorname{lgcgenomics.com} /$ ) were also screened for polymorphisms. The laboratory methods for SSR and SNP analyses were followed according to Lopez-Vera et al. (19).

To construct the final linkage map, the entire population was genotyped using polymorphic markers. Linkage maps were constructed using inclusive composite interval mapping (CIM) software (17). Recombination frequencies were converted to map distances using the Kosambi mapping function (16). Similarly, the linkage map was ordered and rippled using nearest-neighbor twoopt and sum of adjacent recombination fraction algorithms, respectively (17). A graphical representation of the linkage map was constructed using MapChart 2.2 (43). Furthermore, to examine the association between markers and quantitative resistance, CIM was carried out on chromosome 4AL using disease severity data recorded in the 2010 main season in the RILs. Forward and backward regression method (with probability of 0.1 ) employed in CIM of Windows QTL Cartographer V2.5 (44) was used to control the background, and walk speed of 1.0 centimorgan (cM) was used to detect quantitative trait loci (QTL) above a logarithm of odds (LOD) threshold measured by 1,000 permutation tests.

Validating flanking markers for marker-assisted selection. Two SSR markers (Xwmc219 and Xgwm350) flanking SrND643 were used to haplotype 53 wheat lines that have ND643 in their pedigrees and were selected from the CIMMYT 3rd, 4th, 7th and M8th Stem Rust Resistance Screening Nurseries (SRRSN); the M47th International Bread Wheat Screening Nursery (IBWSN); and the M25th High Rainfall Wheat Screening Nursery (HRWSN) (Table 1). The prefix ' $M$ ' in nursery names represents multiplication for seed before the final nursery list is prepared. Seedling reactions to race TTKSK (isolate 04KEN156/04) were determined at the United States Department of Agriculture-Agricultural Research Service Cereal Disease Laboratory following procedures described by Jin et al. (10). Infection type (IT) data were recorded on the 0 -to-4 scale of Stakman et al. (41), where ITs 0, 1, and 2 (or combinations thereof) were considered resistant and ITs 3 and 4 were susceptible. 
Seedling data for entries from the M47th IBWSN and M25th HRWSN were not available. For all 53 wheat lines, stem rust infection response and severity data were also obtained from the international stem rust nurseries evaluated in the 2008 off season in Kenya (3rd and 4th SRRSN) and the 2013 off season in Kenya (7th SRRSN, M8 ${ }^{\text {th }}$ SRRSN, M47th IBWSN, and M25th HRWSN). The marker haplotype and stem rust phenotype in each line were compared to evaluate the efficiency of the markers in selecting the resistance gene.

\section{RESULTS}

Disease evaluation and inheritance of resistance. Substantial and uniform disease pressure was observed in the field nurseries in both test seasons in 2010. Cacuke displayed MS to S responses, with at least $80 \%$ disease severity. The resistant parent ND643/2*Weebill1 gave M and MR responses during main and off seasons, respectively, and disease severities of 5 to $15 \%$. A wide range of infection responses (MR to $\mathrm{S}$ ) was observed among the
RILs, where disease severity ranged from 5 to $80 \%$. Most RILs produced the same infection responses between the two seasons but a greater number of segregating lines were recorded during the off season. Discrepancy in the classification of four RILs as resistant, with MR-MS reaction in the main season and segregating in the off season, could have been due to a higher level of infection during the off season that caused these resistant RILs to appear as segregating. RILs were classified as resistant or susceptible based on consistent responses over both seasons. To avoid the risk of misclassification, a total of 13 RILs showing inconsistent responses across the two seasons (4 RILs) and heterozygotes (9 RILs) were omitted from further analysis. Of the remaining 110 lines used for analysis, 52 were susceptible and 58 were resistant, thus conforming to monogenic inheritance $\left(\chi^{2}{ }_{1: 1}=0.33, P=0.57\right)$.

Genetic mapping of resistance. Selective genotyping of 46 entries identified a total of 629 polymorphic DArT markers distributed across all 21 wheat chromosomes. At least 12 markers on chromosome 4A showed close linkages with resistance (recombination frequency, $r=0.02$ to 0.15 ). For further analysis,

TABLE 1. Phenotype-based SrND643 postulation and corresponding haplotypes of flanking markers in CIMMYT germplasm

\begin{tabular}{|c|c|c|c|c|c|c|c|c|c|}
\hline SN & $\begin{array}{l}\text { CIMMYT } \\
\text { nursery }^{\mathrm{a}}\end{array}$ & $\begin{array}{c}\text { Entry } \\
\text { number }\end{array}$ & $\mathrm{GID}^{\mathrm{b}}$ & Pedigree & $\begin{array}{l}\text { SR field } \\
\text { response }\end{array}$ & $\begin{array}{l}\text { Seedling reaction } \\
\text { to } \text { TTKSK }^{\mathrm{c}}\end{array}$ & $\begin{array}{l}\text { Postulated } \\
\text { SrND643 }\end{array}$ & $\begin{array}{c}\text { Xwmc219 } \\
(136 \mathrm{bp})\end{array}$ & $\begin{array}{c}\text { Xgwm350 } \\
(148 \mathrm{bp})\end{array}$ \\
\hline 1 & 3rdSRRSN & 6086 & 5535274 & ND643/2*WBLL1 & $5 \mathrm{RMR}$ & $2^{-}$ & + & + & + \\
\hline 2 & 3rdSRRSN & 6087 & 5535275 & ND643/2*WBLL1 & $5 \mathrm{RMR}$ & 2 & + & + & + \\
\hline 3 & 3rdSRRSN & 6088 & 5535276 & ND643/2*WBLL1 & $5 \mathrm{R}$ & 2 & + & + & + \\
\hline 4 & 3rdSRRSN & 6089 & 5535277 & ND643/2*WBLL1 & $5 \mathrm{R}$ & $22^{+}$ & + & + & + \\
\hline 5 & 3rdSRRSN & 6090 & 5535280 & ND643/2*WAXWING & $30 \mathrm{~S}$ & 4 & - & - & - \\
\hline 6 & 3rdSRRSN & 6092 & 5535287 & ND643/2*WAXWING & $15 \mathrm{MS}$ & 3 & - & - & - \\
\hline 7 & 3rdSRRSN & 6093 & 5535312 & ND643//2*PRL/2*PASTOR & $20 \mathrm{~S}$ & 3 & - & - & - \\
\hline 8 & 4thSRRSN & 6035 & 5535271 & ND643/2*WBLL1 & $5 \mathrm{M}$ & 2 & + & + & + \\
\hline 9 & 4thSRRSN & 6036 & 5535285 & ND643/2*WAXWING & $30 \mathrm{~S}$ & $2^{+} 3^{-}$ & - & - & - \\
\hline 10 & 4thSRRSN & 6038 & 5535313 & ND643//2*PRL/2*PASTOR & 5 RMR & 2 & + & + & + \\
\hline 11 & 4thSRRSN & 6039 & 5535350 & ND643/2*WBLL1 & $5 \mathrm{RMR}$ & $22^{+}$ & + & + & + \\
\hline 12 & 4thSRRSN & 6041 & 5535351 & ND643/2*WBLL1 & $5 \mathrm{RMR}$ & $2^{+}$ & + & + & + \\
\hline 13 & 4thSRRSN & 6042 & 5535357 & ND643/2*WBLL1 & $5 \mathrm{RMR}$ & $2^{+}$ & + & + & + \\
\hline 14 & 7thSRRSN & 6110 & 6415386 & $\begin{array}{l}\text { CHIBIA//PRLII/CM65531/3/ } \\
\text { FISCAL/4/ND643/2*WBLL1 }\end{array}$ & $5 \mathrm{M}$ & 2 & + & + & + \\
\hline 15 & 7thSRRSN & 6115 & 6417213 & BECARD//ND643/2*WBLL1 & $15 \mathrm{M}$ & 2 & + & + & + \\
\hline 16 & 7thSRRSN & 6141 & 6416382 & $\begin{array}{l}\text { ND643/2*WBLL1// } \\
\text { ATTILA*2/PBW65/3/ } \\
\text { MUNAL }\end{array}$ & $20 \mathrm{MR}$ & $2+3$ & + & + & + \\
\hline 17 & 7thSRRSN & 6142 & 6417455 & $\begin{array}{l}\text { ND643/2*WBLL1// } \\
\text { ATTILA*2/PBW65/3/ } \\
\text { MUNAL }\end{array}$ & $30 \mathrm{MR}$ & $2+3$ & + & + & + \\
\hline 18 & 7thSRRSN & 6143 & 6416477 & $\begin{array}{l}\text { ND643/2*WBLL1/3/ } \\
\text { KIRITATI//PRL/2*PASTOR/ } \\
\text { 4/KRT// PBW65/2*SERI.1B }\end{array}$ & $5 \mathrm{RMR}$ & $2^{+}$ & + & + & + \\
\hline 19 & 7thSRRSN & 6144 & 6416507 & ND643/2*WBLL1//2*BAJ \#1 & $5 \mathrm{RMR}$ & $2^{+}$ & + & + & + \\
\hline 20 & 7thSRRSN & 6145 & 6416509 & ND643/2*WBLL1//2*BAJ \#1 & 5 RMR & $2+3$ & + & + & + \\
\hline 21 & 7thSRRSN & 6146 & 6417467 & ND643/2*WBLL1//2*BAJ \#1 & $10 \mathrm{RMR}$ & $2^{+}$ & + & + & + \\
\hline 22 & 7thSRRSN & 6147 & 6416530 & $\begin{array}{l}\text { ND643/2*TRCH//BECARD/ } \\
\text { 3/BECARD }\end{array}$ & $70 \mathrm{~S}$ & $3^{+}$ & - & - & - \\
\hline 23 & 7thSRRSN & 6148 & 6417471 & $\begin{array}{l}\text { ND643//2*ATTILA*2/ } \\
\text { PASTOR/3/WBLL1*2/ } \\
\text { KURUKU/4/WBLL1*2/ } \\
\text { BRLG }\end{array}$ & $30 \mathrm{MR}$ & 2 & + & + & + \\
\hline 24 & 7thSRRSN & 6149 & 6417472 & $\begin{array}{l}\text { ND643//2*ATTILA*2/ } \\
\text { PASTOR/3/WBLL1*2/ } \\
\text { KURUKU/4/WBLL1*2/ } \\
\text { BRLG }\end{array}$ & $30 \mathrm{MR}$ & $2^{+}$ & + & + & + \\
\hline 25 & M-8SRRSN & 42 & 6681796 & $\begin{array}{l}\text { ND643/2*WBLL1/4/WHEAR/ } \\
\text { KUKUNA/3/C80.1/ } \\
3 * \text { BATAVIA//2*WBLL1 }\end{array}$ & 5 RMR & 2 & + & + & + \\
\hline 26 & M-8SRRSN & 43 & 6683550 & $\begin{array}{l}\text { ND643/2*WBLL1/4/WHEAR/ } \\
\text { KUKUNA/3/C80.1/ } \\
3 * \text { BATAVIA//2*WBLL1 }\end{array}$ & $5 \mathrm{RMR}$ & $2^{-/ 22^{+}}$ & + & + & + \\
\hline 27 & M-8SRRSN & 44 & 6683560 & ND643/2*WBLL1//KACHU & $10 \mathrm{M}$ & $22^{+}$ & + & $\begin{array}{c}+ \\
\text { (continued }\end{array}$ & $\begin{array}{c}+ \\
\text { next page })\end{array}$ \\
\hline
\end{tabular}

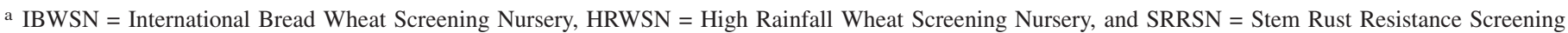

Nursery; M represents the multiplication for seed before final nursery list is prepared.

b Germplasm identification number, a unique identifier of CIMMYT germplasm.

c $\mathrm{NA}=$ not available. 
the closest marker, $w P t-7590(r=0.02)$, was selected for designing polymerase chain reaction (PCR) primers. Among the SSR and SNP markers screened, seven SSR markers (Xbarc78, Xgwm160, Xwmc722, Xwmc497, Xwmc776, Xgwm350, and Xwmc219) and one SNP (BS00016097) marker showed distinct polymorphisms between the parents and respective bulks. In order to construct the final genetic map, polymorphic SSR, SNP, and DArT-PCR markers were used to genotype the whole mapping population of 123 RILs.

Before linkage maps were constructed, the segregation distortions of all markers were analyzed using $\chi^{2}$ tests, and all nine markers conformed to 1:1 segregation ratios of parental alleles $(P=$ 0.09 to 0.80$)$. A partial genetic map of chromosome $4 \mathrm{~A}$ was constructed with a total genetic distance of $31.2 \mathrm{cM}$, in which the stem rust resistance locus $\mathrm{SrND} 643$ was mapped between markers $X g w m 350$ and $X w m c 219$ at distances of $0.5 \mathrm{cM}$ proximal and $4.1 \mathrm{cM}$ distal, respectively (Fig. 1). Markers Xbarc78, Xgwm160, wPt$7590, X g w m 350$, and $X w m c 219$ were previously placed in the most distal deletion bin (4AL4-0.8-1.0) of 4AL $(7,40,45)$. Therefore, SrND643 is located at the distal end of chromosome 4AL. The marker order in the 4AL partial genetic map is consistent with most previously published maps, including the microsatellite consensus map of Somers et al. (38). The SrND643 flanking markers Xgwm350 and Xwmc219 produced PCR fragments of 148 and $136 \mathrm{bp}$, respectively. To further verify the source of $\operatorname{SrND643}$, the two parents, ND643 and Weebill1, of line ND643/*Weebill1 were analyzed with both flanking markers. For both markers, only the PCR fragments amplified from ND643 were similar (148 and 136 bp with Xgwm350 and Xwmc219 primers, respectively) to that of line ND643/*2Weebill1, confirming that SrND643 was inherited from ND643.

TABLE 1. (continued from preceding page)

\begin{tabular}{|c|c|c|c|c|c|c|c|c|c|}
\hline SN & $\begin{array}{l}\text { CIMMYT } \\
\text { nursery }^{\mathrm{a}}\end{array}$ & $\begin{array}{l}\text { Entry } \\
\text { number }\end{array}$ & $\mathrm{GID}^{\mathrm{b}}$ & Pedigree & $\begin{array}{l}\text { SR field } \\
\text { response }\end{array}$ & $\begin{array}{l}\text { Seedling reaction } \\
\text { to } \mathrm{TTKSK}^{\mathrm{c}}\end{array}$ & $\begin{array}{l}\text { Postulated } \\
\text { SrND643 }\end{array}$ & $\begin{array}{l}X w m c 219 \\
(136 \mathrm{bp})\end{array}$ & $\begin{array}{l}\text { Xgwm350 } \\
(148 \mathrm{bp})\end{array}$ \\
\hline 28 & M-8SRRSN & 198 & 6680756 & ND643/2*WBLL1//BECARD & $5 \mathrm{M}$ & 2 & + & + & + \\
\hline 29 & M-8SRRSN & 295 & 6681194 & ND643/2*WBLL1//2*KACHU & $5 \mathrm{M}$ & $22^{+}$ & + & + & + \\
\hline 30 & M-8SRRSN & 296 & 6567022 & $\begin{array}{l}\text { ND643/2*WBLL1//KIRITATI/ } \\
2 * \text { TRCH/3/ND643/ } \\
2 * \text { WBLL1 }\end{array}$ & $15 \mathrm{M}$ & 2 & + & + & + \\
\hline 31 & M-8SRRSN & 297 & 6681200 & $\begin{array}{l}\text { ND643/2*WBLL1/4/CHIBIA// } \\
\text { PRLII/CM65531/3/SKAUZ/ } \\
\text { BAV92/5/BECARD }\end{array}$ & $10 \mathrm{M}$ & 2 & + & + & + \\
\hline 32 & M-8SRRSN & 396 & 6685270 & ND643/2*WBLL1//HEILO & $5 \mathrm{M}$ & $22^{+}$ & + & + & + \\
\hline 33 & M-8SRRSN & 397 & 6685271 & ND643/2*WBLL1//HEILO & $10 \mathrm{M}$ & 2 & + & + & + \\
\hline 34 & M-8SRRSN & 429 & 6684608 & ND643/2*WBLL1//BECARD & $15 \mathrm{MR}$ & 2 & + & + & + \\
\hline 35 & M-8SRRSN & 446 & 6684742 & $\begin{array}{l}\text { ND643/2*WBLL1/4/CHIBIA// } \\
\text { PRLII/CM65531/3/SKAUZ/ } \\
\text { BAV92/5/BECARD }\end{array}$ & $5 \mathrm{MR}$ & 2 & + & + & + \\
\hline 36 & M-8SRRSN & 447 & 6684751 & $\begin{array}{l}\text { ND643/2*WBLL1/4/CHIBIA// } \\
\text { PRLII/CM65531/3/SKAUZ/ } \\
\text { BAV92/5/BECARD }\end{array}$ & $10 \mathrm{RMR}$ & $23^{-}$ & + & + & + \\
\hline 37 & M-8SRRSN & 448 & 6684770 & $\begin{array}{l}\text { ND643/2*WBLL1/3/ } \\
\text { KIRITATI//2*PRL/ } \\
2 * \text { PASTOR/4/BECARD }\end{array}$ & $10 \mathrm{M}$ & $2^{+} 3^{-}$ & + & + & + \\
\hline 38 & M25HRWSN & 1015 & 6570095 & ND643/2*WBLL1//KACHU & $10 \mathrm{M}$ & NA & + & + & + \\
\hline 39 & M25HRWSN & 1017 & 6684812 & ND643/2*WBLL1//KACHU & $5 \mathrm{M}$ & NA & + & + & + \\
\hline 40 & M25HRWSN & 1018 & 6684970 & ND643/2*WBLL1//KACHU & $10 \mathrm{MR}$ & NA & + & + & + \\
\hline 41 & M25HRWSN & 1021 & 6684981 & $\begin{array}{l}\text { ND643/2*WBLL1/3/ } \\
\text { KIRITATI//2*PRL/ } \\
2 * \text { PASTOR }\end{array}$ & $5 \mathrm{MR}$ & NA & + & + & + \\
\hline 42 & M25HRWSN & 1076 & 6569660 & $\begin{array}{l}\text { ND643/2*WBLL1/3/ } \\
\text { BERKUT//PBW343*2/ } \\
\text { KUKUNA }\end{array}$ & $5 \mathrm{M}$ & NA & + & + & + \\
\hline 43 & M25HRWSN & 1077 & 6569788 & $\begin{array}{l}\text { ND643/2*WAXWING//SAAR/ } \\
2 * \text { WAXWING }\end{array}$ & $5 \mathrm{R}$ & NA & + & + & + \\
\hline 44 & M25HRWSN & 1121 & 6684735 & ND643/2*WBLL1//2*KACHU & $5 \mathrm{M}$ & NA & + & + & + \\
\hline 45 & M25HRWSN & 1123 & 6684748 & $\begin{array}{l}\text { ND643/2*WBLL1/4/CHIBIA// } \\
\text { PRLII/CM65531/3/SKAUZ/ } \\
\text { BAV92/5/BECARD }\end{array}$ & $10 \mathrm{M}$ & NA & + & + & + \\
\hline 46 & M25HRWSN & 1125 & 6684759 & $\begin{array}{l}\text { ND643/2*WBLL1/4/CHIBIA// } \\
\text { PRLII/CM65531/3/SKAUZ/ } \\
\text { BAV92/5/BECARD }\end{array}$ & $10 \mathrm{M}$ & NA & + & + & + \\
\hline 47 & M25HRWSN & 1126 & 6684761 & $\begin{array}{l}\text { ND643/2*WBLL1/4/CHIBIA// } \\
\text { PRLII/CM65531/3/SKAUZ/ } \\
\text { BAV92/5/BECARD }\end{array}$ & $10 \mathrm{M}$ & NA & + & + & + \\
\hline 48 & M25HRWSN & 1127 & 6684767 & $\begin{array}{l}\text { ND643/2*WBLL1/3/ } \\
\text { KIRITATI//2*PRL/ } \\
2 * \text { PASTOR/4/BECARD }\end{array}$ & $10 \mathrm{M}$ & NA & + & + & + \\
\hline 49 & M25HRWSN & 1129 & 6684771 & $\begin{array}{l}\text { ND643/2*WBLL1/3/ } \\
\text { KIRITATI//2*PRL/ } \\
2 * \text { PASTOR/4/BECARD }\end{array}$ & $10 \mathrm{M}$ & NA & + & + & + \\
\hline 50 & M47IBWSN & 91 & 6681793 & $\begin{array}{l}\text { ND643/2*WBLL1/4/WHEAR/ } \\
\text { KUKUNA/3/C80.1/ } \\
3 * \text { BATAVIA//2*WBLL1 }\end{array}$ & $10 \mathrm{MR}$ & NA & + & + & + \\
\hline 51 & M47IBWSN & 92 & 6681794 & $\begin{array}{l}\text { ND643/2*WBLL1/4/WHEAR/ } \\
\text { KUKUNA/3/C80.1/ } \\
3 * \text { BATAVIA//2*WBLL1 }\end{array}$ & $5 \mathrm{MR}$ & NA & + & + & + \\
\hline 52 & M47IBWSN & 650 & 6679711 & $\mathrm{ND} 643 / 2 * \mathrm{WBLL} 1 / / 2 * \mathrm{KACHU}$ & $40 \mathrm{~S}, 30 \mathrm{M}$ & NA & - & - & - \\
\hline 53 & M47IBWSN & 652 & 6681187 & ND643/2*WBLL1//2*KACHU & $10 \mathrm{MSS}$ & NA & - & - & - \\
\hline
\end{tabular}


CIM identified a QTL with peak LOD score of 15.06 between markers $X g w m 350(0.5 \mathrm{cM})$ and Xwmc219 $(4.1 \mathrm{cM})$, exactly the same place where $S r N D 643$ was mapped using binary classification of RILs (Fig. 1). With 1 LOD confidence interval, the QTL region spanned approximately $2.1 \mathrm{cM}$ between the flanking markers. This QTL explained $39.7 \%$ of total variation in disease severity, with an additive effect of 11.89 (expressed as percent disease severity).

Effect of SrND643 on stem rust disease severity. To analyze the effect of SrND643 on disease severity, all RILs were reclassified into resistant $(+S r N D 643)$ and susceptible (-SrND643) groups, based on the flanking markers Xgwm350 and Xwmc219. Among 110 RILs, only one recombinant was observed between SrND643 and Xgwm350, whereas eight recombinants were present between $S r N D 643$ and $X w m c 219$. Based on both flanking markers, 96 nonrecombinant RILs (50 +SrND654 and 46 -SrND654, excluding the RILs with missing data for either marker) were used for this analysis. In all cases, + SrND643 lines always displayed MR or $\mathrm{M}$ infection responses in the field. Conversely, -SrND643 RILs always displayed compatible infection responses (MS, MSS, or S). The disease severity on $+\operatorname{SrND643}$ lines was 5 to $40 \%$ (mean = $12 \%)$, whereas it was 10 to $90 \%$ (mean $=38 \%)$ in - SrND643 lines (Fig. 2). The mean difference between the two groups was highly significant $(t$ value $=9.09, P<0.0001)$, indicating that $S r N D 643$ also confers significant effects on disease severity reduction.

Validation of flanking markers for marker-assisted selection. To assess the effectiveness of marker-assisted selection for $S r N D 643$, we haplotyped 53 CIMMYT advanced lines derived from ND643 using the flanking markers Xgwm350 and Xwmc219 (Table 1). Based on field and seedling disease data, 46 lines were postulated to carry SrND643 (Table 1). In all 46 lines, Xgwm350 and Xwmc219 primers amplified 148- and 136-bp fragments, respectively, thereby predicting the presence of $\operatorname{SrND643.~The~}$ seedling ITs in most of the $S r N D 643$ postulated lines ranged from $2^{-}$to $22^{+}$; five lines produced ITs of $23^{-}$or $2^{+} 3^{-}$, whereas the disease severities in the field were 5 to $40 \%$, with infection responses ranging from $\mathrm{R}$ to $\mathrm{M}$. For the seven lines not postulated to carry SrND643, flanking markers did not amplify the SrND643associated allele fragments. ITs for these lines were $3,3^{+}$, or 4 , except 'ND643/2*Waxwing' from the 4th SRRSN that showed an intermediate IT of $2^{+} 3^{-}$. Disease severities for these lines were 10 to $70 \%$, with infection responses of MS to S, except for 'ND643/ $2 *$ Weebill1//2*Kachu' from M47th IBWSN, for which a few plants displayed $\mathrm{M}$ responses (Table 1). Generally, the two flanking markers $X g w m 350$ and $X w m c 219$ were strongly predictive of the presence of $\operatorname{SrND643}$, and all lines carrying the SrND643-linked marker alleles were resistant to TTKSK in seedling tests and resistant to TTKST in field tests.

\section{DISCUSSION}

Using selective genotyping and bulk segregant analysis methods, a new gene or allele, SrND643, effective against the Ug99 group of $P$. graminis f. sp. tritici races, was mapped on the long arm of chromosome 4A. This gene is found in the resistant line ND643/ $2 *$ Weebill1, which has been a common parent in the CIMMYT bread wheat improvement program since its development in 2007. Therefore, it is expected that $\operatorname{SrND643}$ is already widely present in recently developed advanced lines resistant to $P$. graminis f. sp. tritici races in the Ug99 lineage. Though this gene sometimes confers only moderate resistance, its effectiveness is significantly enhanced by genetic background. SrND643 was mapped $0.5 \mathrm{cM}$

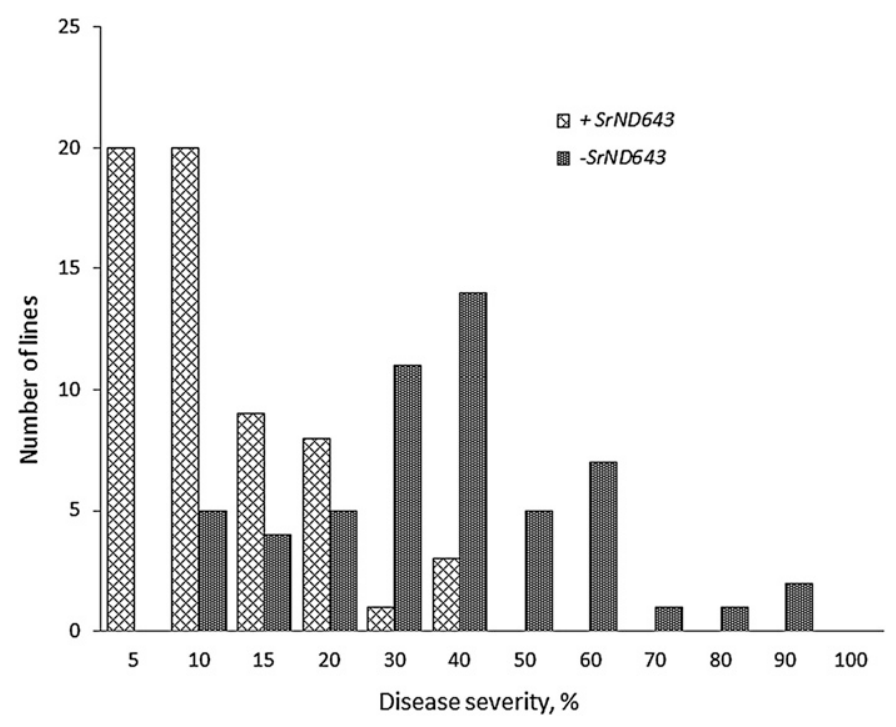

Fig. 2. Distribution of disease severity among Cacuke//ND643/2*Weebill1derived recombinant inbred lines with (+) or without (-) SrND643. Data were collected in the 2010 main season at Njoro, Kenya.

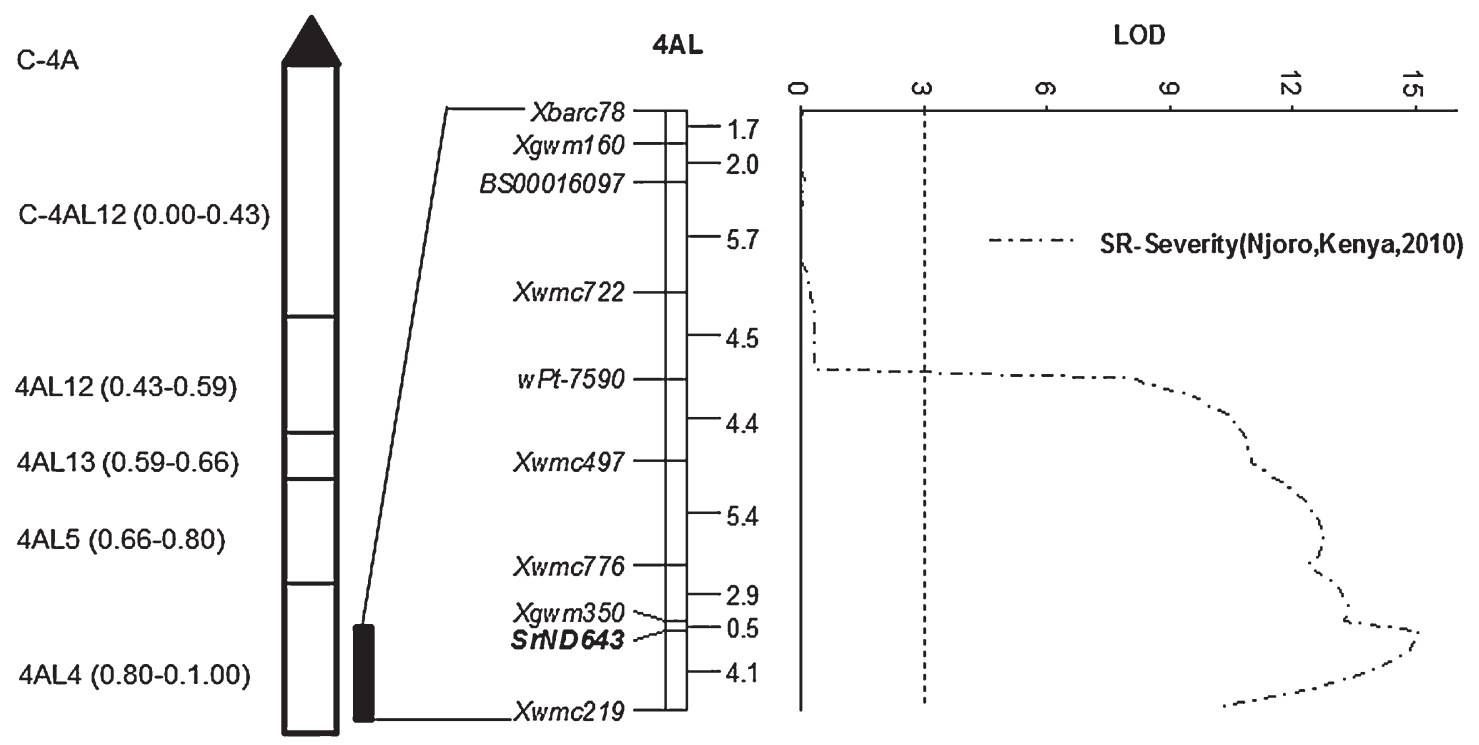

Fig. 1. Genetic position of $\operatorname{SrND} 643$ on a partial linkage map of 4AL, with the corresponding physical bin map. Genetic distances between the markers are given in centimorgans. LOD = logarithm of odds. 
from its closest marker, Xgwm350; therefore, marker-assisted selection or backcrossing could be used to transfer it to new germplasm.

To this date, only one stem rust resistance locus, $\mathrm{Sr} 7$, has been located on chromosome 4A, using monosomic analyses $(14,15)$. Telocentric mapping showed that $\operatorname{Sr} 7$ is genetically independent of the centromere (R. A. McIntosh, unpublished) (20). It was originally identified in several Kenyan wheat varieties, such as 'Kenya Farmer', 'Kenya 117A', and 'Kenya Governor' $(14,15)$, and was later transferred to 'Marquis' and other non-Kenyan lines from Kenya 117A (8). Loegering and Sears (18) reported a different allele, $S r 7 b$, in 'Hope' wheat. Although this allele was commonly present in older Australian, European, North American, and CIMMYT wheat germplasm, it was not deliberately selected as a source of stem rust resistance (20). Because $\operatorname{Sr} 7$ has not been genetically mapped with molecular markers, it is very difficult to compare its location with that of SrND643. However, in contrast to SrND643, which displays an intermediate IT of 2 to $22^{+}$to race TTKSK, reference genotypes possessing $S r 7 a$ and $S r 7 b$ are susceptible to race TTKSK $(10,11)$. Markers Xgwm350 and Xwmc219 flanking SrND643 amplified 139- and 218-bp PCR fragments, respectively, on ISr7b-Ra, the differential genotype of Sr7b. Similarly, Xgwm350 amplified 139 bp and Xwmc 219 failed to amplify any fragment (null allele) on 'Kenya Governor/10*Mq// 8*LMPG' ( $\mathrm{Sr} 7 \mathrm{a}$ differential). For both SSR markers, alleles amplified from $S r 7 a$ - and $S r 7 b$-carrying lines were different from ND643 (148 bp for Xgwm350 and 136 bp for Xwmc219). Therefore, we conclude that $\operatorname{SrND643}$ is a new gene or $\mathrm{Sr} 7$ allele mapped to chromosome arm 4AL.

In association studies on CIMMYT wheat germplasm, Crossa et al. (6) and Yu et al. $(46,47)$ reported that some closely linked DArT markers on chromosome 4AL (wPt-4487, wPt-7807, wPt$3795, w P t 5749, w P t-5857$, and $w P t-3349$ ) were associated with stem rust resistance prior to the emergence of races in the Ug99 lineage. It is likely that the resistance loci reported in the above association studies may represent genes other than SrND643, because this gene was introduced to the breeding program along with ND643 and has not been identified in older CIMMYT germplasm. We were not able to confirm the relationship of resistance reported through association analysis and $\operatorname{SrND643}$ because our 4AL partial map does not have any markers in common with the studies by Crossa et al. (6) and Yu et al. $(46,47)$.

In this study, RILs carrying SrND643 were observed to have disease severities of 5 to $40 \%$ (Fig. 2). However, these lines still displayed incompatible reactions to $P$. graminis $\mathrm{f}$. $\mathrm{sp}$. tritici, with infection responses of $\mathrm{R}, \mathrm{MR}$, or $\mathrm{M}$. On the other hand, in the absence of SrND643, disease severities of the RILs were 10 to $90 \%$, with corresponding infection responses of MS to $\mathrm{S}$. This indicates that, for $\operatorname{SrND643}$, disease severity per se was not useful for determining the presence or absence of $\operatorname{SrND643}$. Similar results were reported by Singh et al. (36), where CIMMYT advanced lines with the race-specific genes Sha7 and SrTmp displayed 1 to 30 and 5 to $60 \%$ disease severities, respectively, accompanied by R or MR infection responses. Our study did not determine what causes the variation in disease severity or within resistant and susceptible infection response classes separately. Possible explanations for this variation include the presence of quantitative adult plant resistance genes and the presence of modifier genes that interact with SrND643.

Markers Xgwm350 and Xwmc219 were validated for their usefulness in selecting the SrND643 gene in ND643-derived CIMMYT lines. Advanced lines were developed by a selectedbulk approach, where segregating populations went through at least one season of selection for leaf rust and yellow rust resistance in Mexico and two seasons of selection for stem rust in Kenya. Lines were then derived by selecting single plants in the $F_{5}$ or $F_{6}$ generations, and were further evaluated for disease resistance, yield, and quality traits in subsequent breeding cycles. About 1,500 advanced lines that met the evaluation criteria were considered as candidates for inclusion in international bread wheat nurseries, including IBWSN, HRWSN, and SRRSN. Because ND643 was identified to carry resistance effective against races in the Ug99 lineage, its derivatives were continuously used as potential parents in crossing blocks of the CIMMYT bread wheat improvement program. SrND643 is a moderately effective gene; thus, its postulation based on field data often becomes a difficult task in advanced breeding lines. This study established that $\operatorname{SrND643}$ is flanked by markers Xgwm350 and Xwmc219, which should make it easier and more efficient to postulate and select in the future. However, SrND643 should be combined with slow-rusting APR genes to achieve low disease severity under high stem rust pressures.

Recently, several advanced lines from CIMMYT's 8th SRRSN and candidate 9th SRRSN were evaluated against different $P$. graminis f. sp. tritici races, including race TKTTF, a newly identified virulent race in Ethiopia. The lines carrying SrND643 were observed to be effective against diverse races, including TTKSK (IT 2 to $22^{+}$), TTKST (2- to $\left.2^{+}\right)$, QFCSC ( 0 ; to ; 1 ), QTHJC (0 to 2$), \operatorname{MCCFC}\left(0\right.$ to ;), RCRSC (0 to $\left.2^{-}\right), \operatorname{RKQQC}\left(0 ;\right.$ to $\left.22^{+}\right)$, TPMKC (;1- to $\left.22^{+}\right)$, and TKTTF (0 to 2$)$. These data suggest that the SrND643 gene is effective to the North American and East African $P$. graminis f. sp. tritici races. As a moderately effective and race-specific gene that expresses at the seedling and adult plant stages, SrND643 can be deployed in new cultivars in conjunction with other all-stage resistance genes (such as $\mathrm{Sr} 33, \mathrm{Sr} 35$, and $\mathrm{Sr} 42$ ) or genes effective only at the adult plant stage (such as $\operatorname{Sr} 2, \operatorname{Sr} 55$, Sr57, and Sr58). Closely linked molecular markers Xgwm350 and $X w m c 219$ are reliable for screening and selection of SrND643 via marker-assisted selection.

\section{ACKNOWLEDGMENTS}

We thank the Durable Rust Resistance in Wheat project, supported by the Bill \& Melinda Gates Foundation and managed by Cornell University; R. McIntosh for technical editing; and E. Quilligan for language editing of this manuscript.

\section{LITERATURE CITED}

1. Akbari, M., Wenzl, P., Caig, V., Carling, J., Xia, L., Yang, S., Uszynski, G., Mohler, V., Lehmensiek, A., Kuchel, H., Hayden, M. J., Howes, N., Sharp, P., Vaughan, P., Rathmell, B., Huttner, E., and Kilian, A. 2006. Diversity arrays technology (DArT) for high-throughput profiling of the hexaploid wheat genome. Theor. Appl. Genet. 113:1409-1420.

2. Ayliffe, M., Periyannan, S. K., Feechan, A., Dry, I., Schumann, U., Wang, M. B., Pryor, A., and Lagudah, E. 2013. A simple method for comparing fungal biomass in infected plant tissues. Mol. Plant-Microbe Interact. 26: 658-667.

3. Basnet, B. R., Singh, R. P., Herrera-Foessel, S. A., Ibrahim, A. M. H., Huerta-Espino, J., Calvo-Salazar, V., and Rudd, J. C. 2013. Genetic analysis of adult plant resistance to yellow rust and leaf rust in common spring wheat Quaiu 3. Plant Dis. 97:728-736.

4. Basnet, B. R., Singh, R. P., Ibrahim, A. M. H., Herrera-Foessel, S. A., Huerta-Espino, J., Lan, C., and Rudd, J. C. 2014. Characterization of Yr54 and other genes associated with adult plant resistance to yellow rust and leaf rust in common wheat Quaiu 3. Mol. Breed. 33:385-399.

5. CIMMYT. 2005. Laboratory Protocols: CIMMYT Applied Molecular Genetics Laboratory, 3rd ed. CIMMYT, Mexico.

6. Crossa, J., Burgueno, J., Dreisigacker, S., Vargas, M., Herrera-Foessel, S. A., Lillemo, M., Singh, R. P., Trethowan, R., Warburton, M., Franco, J., Reynolds, M., Crouch, J. H., and Ortiz, R. 2007. Association analysis of historical bread wheat germplasm using additive genetic covariance of relatives and population structure. Genetics 177:1889-1913.

7. Gadaleta, A., Giancaspro, A., Giove, S. L., Zacheo, S., Mangini, G., Simeone, R., Signorile, A., and Blanco, A. 2009. Genetic and physical mapping of new EST-derived SSRs on the A and B genome chromosomes of wheat. Theor. Appl. Genet. 118:1015-1025.

8. Green, G. J., Knott, D. R., Watson, I. A., and Pugsley, A. T. 1960. Seedling reactions to stem rust of lines of Marquis wheat with substituted genes for rust resistance. Can. J. Plant Sci. 40:524-538. 
9. Hiebert, C. W., Fetch, T. G., Zegeye, T., Thomas, J. B., Somers, D. J., Humphreys, D. G., McCallum, B. D., Cloutier, S., Singh, D., and Knott, D. R. 2011. Genetics and mapping of seedling resistance to Ug99 stem rust in Canadian wheat cultivars "Peace" and "AC Cadillac". Theor. Appl. Genet. 122:143-149.

10. Jin, Y., Singh, R. P., Ward, R. W., Wanyera, R., Kinyua, M., Njau, P., Fetch, T., Pretorius, Z. A., and Yahyaoui, A. 2007. Characterization of seedling infection types and adult plant infection responses of monogenic $\mathrm{Sr}$ gene lines to race TTKS of Puccinia graminis f. sp. tritici. Plant Dis. 91:1096-1099.

11. Jin, Y., Szabo, L. J., Pretorius, Z. A., Singh, R. P., Ward, R., and Fetch, T. 2008. Detection of Virulence to resistance gene $\mathrm{Sr} 24$ within race TTKS of Puccinia graminis f. sp. tritici. Plant Dis. 92:923-926.

12. Jin, Y., Szabo, L. J., Rouse, M. N., Fetch, T., Pretorius, Z. A., Wanyera, R., and Njau, P. 2009. Detection of virulence to resistance gene Sr36 within the TTKS Race Lineage of Puccinia graminis f. sp. tritici. Plant Dis. 93: 367-370.

13. Khan, K., Frohberg, R., Olson, T., and Huckle, L. 1989. Inheritance of gluten protein components of high-protein hard red spring wheat lines derived from Triticum turgidum var. dicoccoides. Cereal Chem. 66: 397-401.

14. Knott, D. R. 1959. The inheritance of rust resistance. IV. Monosomic analysis of rust resistance and some other characters in six varieties of wheat including Gabo and Kenya Farmer. Can. J. Plant Sci. 39:215-228.

15. Knott, D. R., and Anderson, R. G. 1956. The inheritance of rust resistance. I. The inheritance of stem rust resistance in ten varieties of common wheat. Can. J. Agric. Sci. 36:174-195.

16. Kosambi, D. 1943. The estimation of map distances from recombination values. Ann. Eugen. 12:172-175.

17. Li, H., Ribaut, J.-M., Li, Z., and Wang, J. 2008. Inclusive composite interval mapping (ICIM) for digenic epistasis of quantitative traits in biparental populations. Theor. Appl. Genet. 116:243-260.

18. Loegering, W. Q., and Sears, E. R. 1966. Relationships among stem-rust genes on wheat chromosomes 2B, 4B and 6B. Crop Sci. 6:157-160.

19. Lopez-Vera, E. E., Nelson, S., Singh, R. P., Basnet, B. R., Haley, S. D., Bhavani, S., Huerta-Espino, J., Xoconostle-Cazares, B., Ruiz-Medrano, R., Rouse, M. N., and Singh, S. 2014. Resistance to stem rust Ug99 in six bread wheat cultivars maps to chromosome 6DS. Theor. Appl. Genet. 127: 231-239.

20. McIntosh, R. A., Wellings, C. R., and Park, R. F. 1995. Page 205 in: Wheat Rusts: An Atlas of Resistance Genes. CSIRO Publications, Australia.

21. McIntosh, R. A., Yamazaki, Y. Y., Dubcovsky, J., Rogers, W. J., Morris, C., Somers, D. J., Appels, R., and Devos, K. M. 2012. MacGene 2012: Catalogue of gene symbols for wheat. http://www.shigen.nig.ac.jp/wheat/ komugi/genes/download.jsp\#mg2012

22. Nagarajan, S., and Joshi, L. M. 1975. An historical account of wheat rust epidemics in India and their significance. Cereal Rust Bull. 2:29-33.

23. Njau, P. N., Bhavani, S., Huerta-Espino, J., Keller, B., and Singh, R. P. 2013. Identification of QTL associated with durable adult plant resistance to stem rust race Ug99 in wheat cultivar "Pavon 76.". Euphytica 190: 33-44.

24. Pardey, P. G., Beddow, J. M., Kriticos, D. J., Hurley, T. M., Park, R. F., Duveiller, E., Sutherst, R. W., Burdon, J. J., and Hodson, D. 2013. Rightsizing stem-rust research. Science 340:147-148.

25. Periyannan, S., Moore, J., Ayliffe, M., Bansal, U., Wang, X., Huang, L., Deal, K., Luo, M., Kong, X., Bariana, H., Mago, R., McIntosh, R., Dodds, P., Dvorak, J., and Lagudah, E. 2013. The gene Sr33, an ortholog of barley Mla genes, encodes resistance to wheat stem rust race Ug99. Science 341: 786-788.

26. Peterson, R. F., Campbell, A. B., and Hannah, A. E. 1948. A diagrammatic scale for estimating rust intensity on leaves and stems of cereals. Can. J. Res. 26c:496-500.

27. Pretorius, Z. A., Singh, R. P., Wagoire, W. W., and Payne, T. S. 2000. Detection of virulence to wheat stem rust resistance gene Sr31 in Puccinia graminis f. sp. tritici in Uganda. Plant Dis. 84:203.2.
28. Roelfs, A. P. 1978. Estimated losses caused by rust in small grains cereals in the United States-1918-76.Misc. Publ. U. S. Dep. Agric. 1363:1-26.

29. Roelfs, A. P., and Martens, J. W. 1988. An international system of nomenclature for Puccinia graminis f. sp. tritici. Phytopathology 78: 526-533.

30. Roelfs, A. P., Singh, R. P., and Saari, E. E. 1992:Page 81 in: Rust Diseases of Wheat: Concepts and Methods of Disease Management. CIMMYT, Mexico.

31. Saari, E. E., and Prescott, J. M. 1985. World distribution in relation to economic losses. Pages 236-271 in: The Cereal Rusts, Volume II: Diseases, Distribution, Epidemiology and Control. A. P. Roelfs and W. R. Bushnell, eds. Academic Press Inc., Orlando, FL.

32. Saintenac, C., Zhang, W., Salcedo, A., Rouse, M. N., Trick, H. N., Akhunov, E., and Dubcovsky, J. 2013. Identification of Wheat Gene Sr35 That Confers Resistance to Ug99 Stem Rust Race Group. Science 341: 783-786.

33. Singh, D., Park, R., McIntosh, R., and Bariana, H. 2008. Characterisation of stem rust and stripe rust seedling resistance genes in selected wheat cultivars from the United Kingdom. J. Plant Pathol. 90:553-562.

34. Singh, R. P., Hodson, D. P., Huerta-Espino, J., Jin, Y., Bhavani, S., Njau, P., Herrera-Foessel, S., Singh, P. K., Singh, S., and Govindan, V. 2011. The emergence of Ug99 races of the stem rust fungus is a threat to world wheat production. Annu. Rev. Phytopathol. 49:465-481.

35. Singh, R. P., Hodson, D. P., Huerta-Espino, J., Jin, Y., Njau, P., Wanyera, R., Herrera-Foessel, S. A., and Ward, R. W. 2008. Will stem rust destroy the world's wheat crop? Adv. Agron. 98:271-309.

36. Singh, R. P., Huerta-Espino, J., Bhavani, S., Herrera-Foessel, S. A., Singh, D., Singh, P. K., Velu, G., Mason, R. E., Jin, Y., Njau, P., and Crossa, J. 2011. Race non-specific resistance to rust diseases in CIMMYT spring wheats. Euphytica 179:175-186.

37. Singh, R. P., Huerta-Espino, J., and Rajaram, S. 2000. Achieving nearimmunity to leaf and stripe rusts in wheat by combining slow rusting resistance genes. Acta Phytopathol. Hun. 35:133-139.

38. Somers, D. J., Isaac, P., and Edwards, K. 2004. A high-density microsatellite consensus map for bread wheat (Triticum aestivum L.). Theor. Appl. Genet. 109:1105-1114.

39. Song, Q. J., Fickus, E. W., and Cregan, P. B. 2002. Characterization of trinucleotide SSR motifs in wheat. Theor. Appl. Genet. 104:286-293.

40. Sourdille, P., Singh, S., Cadalen, T., Brown-Guedira, G., Gay, G., Qi, L., Gill, B. S., Dufour, P., Murigneux, A., and Bernard, M. 2004. Microsatellite-based deletion bin system for the establishment of geneticphysical map relationships in wheat (Triticum aestivum L.). Funct. Integr. Genomics 4:12-25.

41. Stakman, E. C., Stewart, D. M., and Loegering, W. Q. 1962. Identification of physiologic races of Puccinia graminis var. tritici. U. S. Dep. Agric. Res. Serv. E-617.

42. Sunderwirth, S. D., and Roelfs, A. P. 1980. Greenhouse characterization of the adult plant resistance of $\mathrm{Sr} 2$ to wheat stem rust. Phytopathology 70: 634-637.

43. Voorrips, R. E. 2002. MapChart: Software for the Graphical Presentation of Linkage Maps and QTLs. J. Hered. 93:77-78.

44. Wang, S., Basten, C. J., and Zeng, Z.-B. 2012. Windows QTL Cartographer 2.5. Department of Statistics, North Carolina State University, Raleigh, NC., http://statgen.ncsu.edu/qtlcart/WQTLCart.htm

45. Wilkinson, P. A., Winfield, M. O., Barker, G. L. A., Allen, A. M., Burridge, A., Coghill, J. A., Burridge, A., and Edwards, K. J. 2012. CerealsDB 2.0: an integrated resource for plant breeders and scientists. BMC Bioinform. 13:219.

46. Yu, L., Lorenz, A., Rutkoski, J., Singh, R. P., Bhavani, S., Julio Huerta-Espino, J., and Sorrells, M. E. 2011. Association mapping and gene-gene interaction for stem rust resistance in CIMMYT spring wheat germplasm. Theor. Appl. Genet. 123:1257-1268.

47. Yu, L., Morgounov, A., Ruth Wanyera, R., Keser, M., Singh, S. K., and Sorrells, M. E. 2012. Identification of Ug99 stem rust resistance loci in winter wheat germplasm using genome-wide association analysis. Theor. Appl. Genet. 125:749-758. 